\title{
Influence of rice varieties and fertility levels on performance of rice and soil nutrient status under aerobic conditions
}

\author{
Sandeep Kumar ${ }^{1 *}$, Sarabdeep Kour ${ }^{2}$, Meenakshi Gupta ${ }^{1}$, Dileep Kachroo ${ }^{1}$ and Hari Singh ${ }^{3}$ \\ ${ }^{1}$ Division of Agronomy, Sher-e-Kashmir University of Agricultural Sciences and Technology of Jammu, Chatha, \\ Jammu-180009 (J\&K), INDIA \\ ${ }^{2}$ Division of Soil Science and Agricultural Chemistry, Sher-e-Kashmir University of Agricultural Sciences and \\ Technology of Jammu, Chatha, Jammu-180009 (J\&K), INDIA \\ ${ }^{3}$ College of Agriculture, Swami Keshwanand Rajasthan Agriculture University, Bikaner (Rajasthan), INDIA \\ *Corresponding author. E-mail: sksandeepkumarrao@gmail.com; hsagro666@gmail.com
}

Received: September 4, 2016; Revised received: February 20, 2017; Accepted: May 20, 2017

\begin{abstract}
Scarcity of water resources in India is limiting the production of flooded rice crop. A field experiment was conducted in factorial RBD with sixteen treatment combinations including four rice varieties viz. $V_{1}$ : PR-115, $V_{2}$ : DRRH-3, $\mathrm{V}_{3}$ : PAC-837 and $\mathrm{V}_{3}$ : PR-121 and four fertility levels viz. $\mathrm{F}_{1}$ : control $\left(\mathrm{N}_{0} \mathrm{P}_{0} \mathrm{~K}_{0}\right), \mathrm{F}_{2}: \mathrm{N}_{2} \mathrm{P}_{2} \mathrm{O}_{5}, \mathrm{~K}_{2} \mathrm{O}$ at $90: 45$ : $22.5 \mathrm{~kg} \mathrm{ha}^{-1}, \mathrm{~F}_{3}: \mathrm{N}, \mathrm{P}_{2} \mathrm{O}_{5}, \mathrm{~K}_{2} \mathrm{O}$ at $120: 60: 30 \mathrm{~kg} \mathrm{ha}^{-1}$ and $\mathrm{F}_{4}: \mathrm{N}, \mathrm{P}_{2} \mathrm{O}_{5}, \mathrm{~K}_{2} \mathrm{O}$ at 150: $75: 37.5 \mathrm{~kg} \mathrm{ha}^{-1}$ replicated thrice. The results revealed that among the different varieties, PAC-837 recorded highest plant height and number of tillers $\mathrm{m}^{-2}$ at all the growth stages. All yield attributes viz. number of effective tillers $\mathrm{m}^{-2}$, number of seeds per panicle, 1000grain weight, spikelet sterility and grain yield, straw yield and harvest index significantly differed in different varieties and were recorded highest in PAC-837 which were however, statistically at par with DRRH-3 except grain yield and effective tillers $\mathrm{m}^{-2}$. Rice variety PAC-837 recorded highest grain yield of $45.65 \mathrm{q} \mathrm{ha}^{-1}$ and straw yield of $59.98 \mathrm{q} \mathrm{ha}{ }^{-1}$. Among the fertility levels, number of effective tillers $\mathrm{m}^{-2}$ significantly increased up to 120: $60: 30 \mathrm{~N}-\mathrm{P}_{2} \mathrm{O}_{5}-\mathrm{K}_{2} \mathrm{O} \mathrm{kg} \mathrm{ha}^{-1}$ thereafter non significant differences were noticed. The grain and straw yield increased up to 150: $75: 37.5 \mathrm{~N}-\mathrm{P}_{2} \mathrm{O}_{5}-$ $\mathrm{K}_{2} \mathrm{O} \mathrm{kg} \mathrm{ha}{ }^{-1}$ and recoded grain yield of $52.78 \mathrm{q} \mathrm{ha}^{-1}$ and straw yield of $73.85 \mathrm{q} \mathrm{ha}^{-1}$ with application of 150:75:37.5 N$\mathrm{P}_{2} \mathrm{O}_{5}-\mathrm{K}_{2} \mathrm{O} \mathrm{kg} \mathrm{ha}^{-1}$. Nutrient application of 150: 75: $37.5 \mathrm{~N}-\mathrm{P}_{2} \mathrm{O}_{5}-\mathrm{K}_{2} \mathrm{O} \mathrm{kg} \mathrm{ha}{ }^{-1}$ recorded highest available N $(238.16 \mathrm{~kg}$ $\left.\mathrm{ha}^{-1}\right), \mathrm{P}\left(16.18 \mathrm{~kg} \mathrm{ha}^{-1}\right)$ and $\mathrm{K}\left(163.25 \mathrm{~kg} \mathrm{ha}^{-1}\right)$ in soil after harvest of the crop. Higher available nitrogen $(235.28 \mathrm{~kg}$ $\left.\mathrm{ha}^{-1}\right)$, phosphorus $\left(16.38 \mathrm{~kg} \mathrm{ha}^{-1}\right)$ and potassium $\left(154.24 \mathrm{~kg} \mathrm{ha}^{-1}\right) \mathrm{n}$ soil were recorded with PR-121 and lowest available major nutrients were recorded with variety PAC-837. This study would help to introduction and adaptation of new rice variety PAC-837 with application of 150: 75: $37.5 \mathrm{~N}-\mathrm{P}_{2} \mathrm{O}_{5}-\mathrm{K}_{2} \mathrm{O} \mathrm{kg}^{-1}{ }^{-1}$ under aerobic conditions in Shiwalik foothills region of North-Western Himalayas.
\end{abstract}

Keywords: Aerobic rice, Fertility levels, Productivity, Soil status, Varieties

\section{INTRODUCTION}

Rice (Oryza sativa L.) is the staple food of about 3 billion people and the demand is expected to continue to grow as population increases (Carriger and Vallee, 2007). India accounts for $22.3 \%$ of the world's production of rice. In India, rice ranks first among all the crops in term of area and production. Rice is cultivated round the year in one or the other part of the country, in diverse ecologies spread over $43.86 \mathrm{M}$ ha with a production of 104.80 million tonnes of rice and average productivity of $23.90 \mathrm{q} \mathrm{ha}^{-1}$ (Anonymous, 2015). In India, Rice is commonly grown by transplanting rice seedlings into puddle soils in Indo-Gangetic plains and other regions. But, over the coming decades, farmers, policy makers and researchers alike will need to adapt to several threats to rice productivity. Of the potential threats, water scarcity and increasing competition for water in irrigated rice systems are perhaps the most pressing in terms of potential impact on overall production levels. Tuong and Bouman (2001) estimated that by 2025 , approximately two million hectare of irrigated dry season rice and thirteen million hectare of wet season rice will experience water scarcity. The increasing water scarcity for agriculture and competition for water from non-agricultural sectors dictate to an urgent need to improve crop water productivity. Hence, water-saving irrigation technologies for rice are seen as a key component to deal with water scarcity in the days to come.

So there is need to focus our research on low water requiring rice growing technologies. Introduction of water-saving aerobic rice can reduce water use in rice production by as much as $50 \%$. The new concept of aerobic rice may be an alternate strategy as compared to traditional rice cultivation system, which combines the characteristics of rice varieties adopted in upland with less water requirement and irrigated varieties with high response to inputs. Aerobic rice promises substan- 


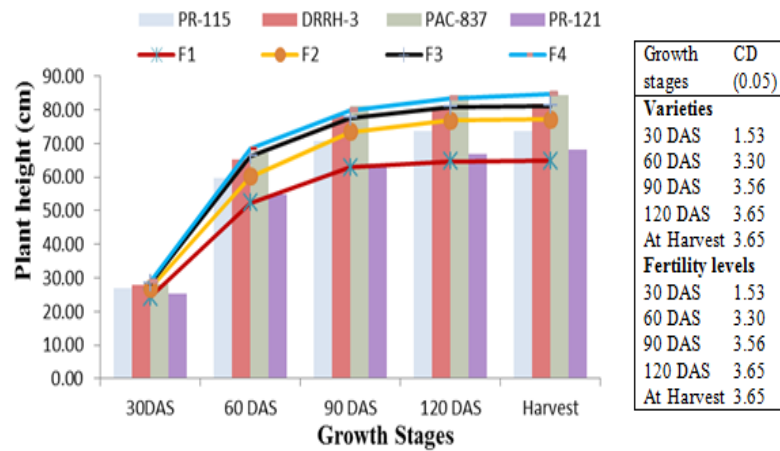

Fig. 1. Effect of different varieties and fertility levels on plant height (cm) at various growth stages.

tial water savings by minimizing seepage and percolation and also greatly reducing evaporation (Bouman et al., 2002). Agronomic practices has great role to play in increasing the yield and productivity of rice. Among different management practices, aerobic rice varieties and fertility levels can prove helpful in realizing the higher yield of rice.

Among the various cultural practices, fertilizer management is crucial factor, which influence the growth and yield of rice. One of the sound principles of aerobic rice is fertilizer management leading to good root development, better tillering potential, higher accumulation of dry matter, and efficient partitioning of dry matter to economically important plant parts. As aerobic rice culture is a new system, there is urgent need to develop suitable nutrient management schedule for this system. Also the nutrient behavior in aerobic soils and in puddled soil is quite different especially in relation to major nutrients. It is therefore, necessary to apply fertilizer elements, particularly $\mathrm{N}, \mathrm{P}$ and $\mathrm{K}$ through inorganic sources in optimal quantity to improve and sustain the productivity (Yoshida, 1981). Moreover prevailing energy crises also necessitates for balanced and proper dose of fertilizers to be applied. The study

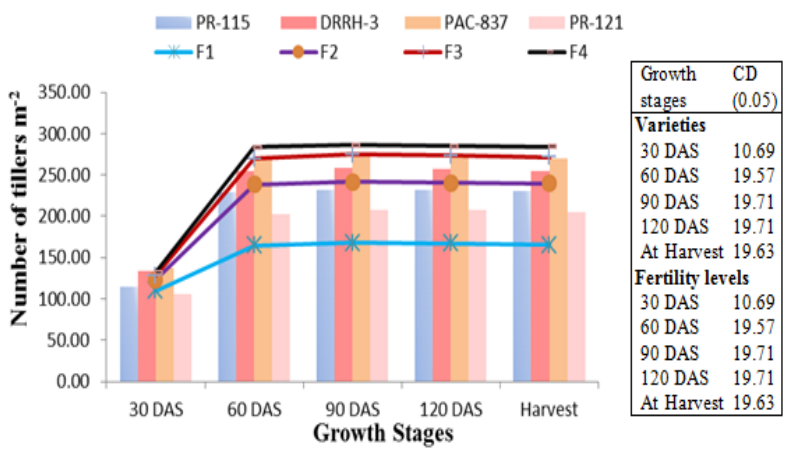

Fig. 2. Effect of different varieties and fertility levels on number of tillers $\mathrm{m}^{-2}$ at various growth stages.

related to varieties suited for aerobic rice and their nutrient demand is meager in Jammu conditions. Keeping in view the apprehensions of water scarcity in coming times particularly in rice growing belt of Jam$\mathrm{mu}$, it seems to be pertinent that the aerobic rice production technology for rice cultivars of this belt needs to be standardized with the use of fertilizers.

\section{MATERIALS AND METHODS}

Experimental details: The field experiment was conducted at Agronomy Research Farm of Sher-eKashmir University of Agricultural Sciences and Technology of Jammu, Chatha (Jammu and Kashmir), India during kharif 2014-15. Geographically, the experimental site was located at $32^{\circ}-40^{\circ}$ North latitude and $74-58^{\circ}$ East longitude with an altitude of 332 meters above mean sea level in the Shiwalik foothills of North -Western Himalayas. The soil at the experimental site was sandy loam in texture with $\mathrm{pH}$ of 8.15 , EC of 0.32 $\mathrm{dS} \mathrm{m} \mathrm{m}^{-1}$, Organic carbon of $4.6 \mathrm{~g} / \mathrm{kg}$, available $\mathrm{N}$ of $233.27 \mathrm{~kg} \mathrm{ha}^{-1}, \mathrm{P}_{2} \mathrm{O}_{5}$ of $13.42 \mathrm{~kg} \mathrm{ha}^{-1}$ and $\mathrm{K}_{2} \mathrm{O}$ of $149.62 \mathrm{~kg} \mathrm{ha}^{-1}$. The experiment, replicated thrice, was laid out in factorial randomized block design with four varieties viz. $\mathrm{V}_{1}$ : PR-115, $\mathrm{V}_{2}$ : DRRH-3, $\mathrm{V}_{3}$ : PAC-837

Table 1. Effect of different rice varieties and fertility levels on yield and yield attributes under aerobic conditions.

\begin{tabular}{|c|c|c|c|c|c|c|c|}
\hline Treatments & Effective tillers $\mathrm{m}^{-2}$ & $\begin{array}{l}\text { Number of } \\
\text { seeds panicle }^{-1}\end{array}$ & $\begin{array}{l}\text { 1000- } \\
\text { grain } \\
\text { weight }\end{array}$ & $\begin{array}{l}\text { Spikelet } \\
\text { sterility } \\
(\%)\end{array}$ & $\begin{array}{l}\text { Grain } \\
\text { yield } \\
\left(\mathrm{q} \mathrm{ha}^{-1}\right)\end{array}$ & $\begin{array}{l}\text { Straw } \\
\text { yield } \\
\left(\mathrm{q} \mathrm{ha} \mathbf{h}^{-1}\right)\end{array}$ & $\begin{array}{l}\text { Harvest } \\
\text { index } \\
(\%) \\
\end{array}$ \\
\hline \multicolumn{8}{|l|}{ Varieties } \\
\hline $\mathrm{V}_{1}:$ PR-115 & 220.17 & 92.92 & 20.99 & 15.23 & 41.06 & 59.50 & 40.17 \\
\hline $\mathrm{V}_{2}:$ DRRH-3 & 236.33 & 98.75 & 19.13 & 16.55 & 43.37 & 58.65 & 42.44 \\
\hline $\mathrm{V}_{3}:$ PAC-837 & 264.00 & 72.17 & 24.17 & 23.21 & 45.65 & 59.98 & 43.12 \\
\hline $\mathrm{V}_{4}:$ PR-121 & 192.50 & 71.17 & 27.33 & 29.89 & 32.99 & 51.42 & 39.36 \\
\hline $\mathrm{SEm} \pm$ & 4.53 & 1.77 & 0.29 & 0.65 & 0.68 & 1.04 & 0.69 \\
\hline CD (0.05) & 13.09 & 5.13 & 0.85 & 1.87 & 1.96 & 3.01 & 1.99 \\
\hline \multicolumn{8}{|c|}{ Fertility Levels $\left(\mathrm{N}-\mathrm{P}_{2} \mathrm{O}_{5}-\mathrm{K}_{2} \mathrm{O} \mathrm{kg} \mathrm{ha}^{-1}\right)$} \\
\hline $\mathrm{F}_{1}: \mathrm{N}_{0} \mathrm{P}_{0} \mathrm{~K}_{0}$ & 155.08 & 67.25 & 22.28 & 27.18 & 20.86 & 31.33 & 40.15 \\
\hline $\mathrm{F}_{2}: \mathrm{N}_{90} \mathrm{P}_{45} \mathrm{~K}_{22.5}$ & 231.17 & 80.50 & 23.08 & 21.75 & 39.22 & 54.85 & 41.57 \\
\hline $\mathrm{F}_{3}: \mathrm{N}_{120} \mathrm{P}_{60} \mathrm{~K}_{30}$ & 260.08 & 90.67 & 23.13 & 18.38 & 50.21 & 69.53 & 41.82 \\
\hline $\mathrm{F}_{4}: \mathrm{N}_{150} \mathrm{P}_{75} \mathrm{~K}_{37.5}$ & 266.67 & 96.58 & 23.14 & 17.57 & 52.78 & 73.85 & 41.56 \\
\hline $\mathrm{SEm} \pm$ & 4.53 & 1.77 & 0.29 & 0.65 & 0.68 & 1.04 & 0.69 \\
\hline CD (0.05) & 13.09 & 5.13 & NS & 1.87 & 1.96 & 3.01 & NS \\
\hline Interaction & NS & $\mathrm{S}$ & NS & NS & $\mathrm{S}$ & $\mathrm{S}$ & NS \\
\hline
\end{tabular}




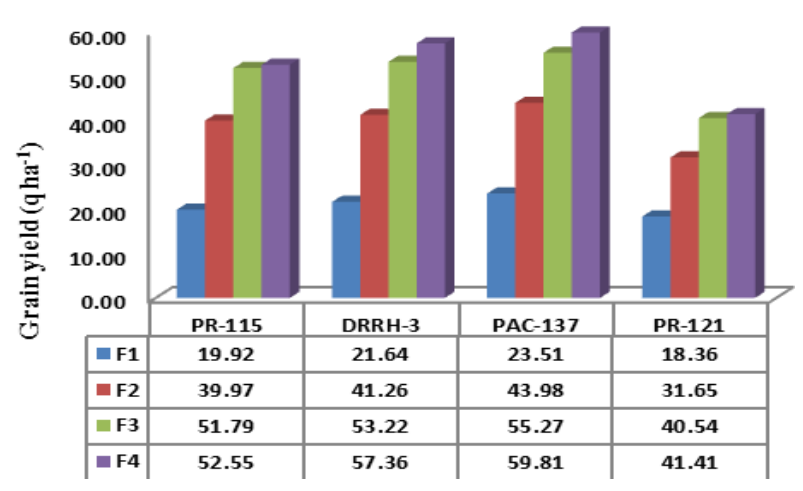

Fig. 3. Interaction effect of different rice varieties and fertility levels on grain yield under aerobic conditions.

and $\mathrm{V}_{4}$ : PR-121 and four fertility levels viz. $\mathrm{F}_{1}$ : control $\left(\mathrm{N}_{0} \mathrm{P}_{0} \mathrm{~K}_{0}\right), \mathrm{F}_{2}: \mathrm{N}, \mathrm{P}_{2} \mathrm{O}_{5}, \mathrm{~K}_{2} \mathrm{O}$ at 90:45:22.5 $\mathrm{kg} \mathrm{ha}^{-1}, \mathrm{~F}_{3}$ : $\mathrm{N}, \mathrm{P}_{2} \mathrm{O}_{5}, \mathrm{~K}_{2} \mathrm{O}$ at 120: 60: $30 \mathrm{~kg} \mathrm{ha}^{-1}$ and $\mathrm{F}_{4}: \mathrm{N}$, $\mathrm{P}_{2} \mathrm{O}_{5}, \mathrm{~K}_{2} \mathrm{O}$ at 150: $75: 37.5 \mathrm{~kg} \mathrm{ha}^{-1}$ under aerobic conditions. The crop was sown on 15 June 2015 at a spacing of $20 \mathrm{~cm}$ rows apart in $15 \mathrm{~m}^{2}$ plot size with a seed rate of 50, 40, 50 and $60 \mathrm{~kg} \mathrm{ha}{ }^{-1}$ for PR-115, DRRH-3, PAC-837 and PR-121, respectively. Half dose of $\mathrm{N}$ and the entire dose of $\mathrm{P}$ and $\mathrm{K}$ were applied at the time of sowing through urea, di-ammonium phosphate and muriate of potash, respectively. Remaining half dose of $\mathrm{N}$ was applied in two equal splits at active tillering and flowering stage. To maintain aerobic conditions, irrigations were applied whenever soil appears to have developed hair line cracks and excess water of rainfall is removed after 24 hours of occurrences.

Growth, yield and yield attribute determination: For all the growth and development studies during the crop growth period, five plants were selected randomly and tagged in each plot. Initially the growth parameters were recorded at 30 days after sowing and subsequent observations were taken at an interval of 30 days. Yield and yield attributing characters was determined using standard procedures. Finally yield was expressed as $\mathrm{q} \mathrm{ha}{ }^{-1}$.

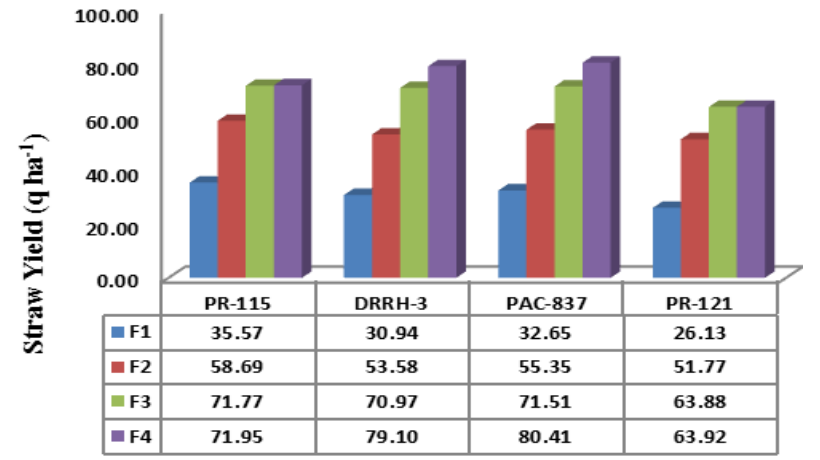

Fig. 4. Interaction effect of different rice varieties and fertility levels on straw yield under aerobic conditions.

Soil chemical analysis: Before sowing of the crop a composite soil sample is taken for determination of $\mathrm{pH}, \mathrm{EC}, \mathrm{OC}$, available nitrogen, phosphorus and potassium and after harvesting of rice crop, individual soil samples from all the plots were taken from the surface for determination of same. Soil $\mathrm{pH}$ and EC was measured in a soil-water suspension using glass electrode $\mathrm{pH}$ meter and systronics conductivity meter, respectively (Jackson, 1967). Soil organic carbon was determined by the rapid titration method (Walkley and Black, 1934), available $\mathrm{N}$ by alkaline Potassium permanganate method (Subbiah and Asija, 1956), available $\mathrm{P}$ by Sodium Bicarbonate method (Olsen et al., 1954) and available K by Ammonium acetate method (Jackson, 1973).

Statistical analysis: The statistical analysis of factorial randomized block design with 4 levels of both two factors was done by standard procedures suggested by Gomez and Gomez (1984).

\section{RESULTS AND DISCUSSION}

Growth and development: Growth parameters like plant height, tillers $\mathrm{m}^{-2}$ and dry matter production of aerobic rice were positively influenced by different

Table 2. Effect of different rice varieties and fertility levels on soil fertility status after harvest under aerobic conditions.

\begin{tabular}{|c|c|c|c|c|c|c|}
\hline \multirow{2}{*}{ Treatments } & \multirow{2}{*}{ Soil pH } & \multirow{2}{*}{$\begin{array}{c}E C \\
\left(\mathrm{dS} \mathrm{m}^{-1}\right) \\
\end{array}$} & \multirow{2}{*}{$\begin{array}{c}\text { Soil O.C. } \\
\left(\mathrm{g} \mathrm{kg}^{-1}\right)\end{array}$} & \multicolumn{3}{|c|}{ Available nutrient status $\left(\mathrm{kg} \mathrm{ha}^{-1}\right)$} \\
\hline & & & & Nitrogen & Phosphorus & Potassium \\
\hline \multicolumn{7}{|l|}{ Varieties } \\
\hline $\mathrm{V}_{1}:$ PR-115 & 8.16 & 0.33 & 4.7 & 223.69 & 12.03 & 143.80 \\
\hline $\mathrm{V}_{2}:$ DRRH-3 & 8.16 & 0.33 & 4.8 & 217.47 & 10.35 & 140.44 \\
\hline $\mathrm{V}_{3}:$ PAC-837 & 8.15 & 0.32 & 4.8 & 214.19 & 9.09 & 138.00 \\
\hline $\mathrm{V}_{4}:$ PR-121 & 8.17 & 0.34 & 4.5 & 235.28 & 16.38 & 154.24 \\
\hline $\mathrm{SEm} \pm$ & 0.02 & 0.01 & 0.00 & 2.84 & 0.66 & 2.89 \\
\hline $\mathrm{CD}(0.05)$ & NS & NS & NS & 8.20 & 1.89 & 8.35 \\
\hline \multicolumn{7}{|c|}{ Fertility Levels $\left(\mathrm{N}-\mathrm{P}_{2} \mathrm{O}_{5}-\mathrm{K}_{2} \mathrm{O} \mathrm{kg} \mathrm{ha}^{-1}\right)$} \\
\hline $\mathrm{F}_{1}: \mathrm{N}_{0} \mathrm{P}_{0} \mathrm{~K}_{0}$ & 8.11 & 0.31 & 4.6 & 201.45 & 6.49 & 112.22 \\
\hline $\mathrm{F}_{2}: \mathrm{N}_{90} \mathrm{P}_{45} \mathrm{~K}_{22.5}$ & 8.16 & 0.33 & 4.6 & 220.85 & 10.78 & 142.85 \\
\hline $\mathrm{F}_{3}: \mathrm{N}_{120} \mathrm{P}_{60} \mathrm{~K}_{30}$ & 8.18 & 0.34 & 4.7 & 230.17 & 14.41 & 158.16 \\
\hline $\mathrm{F}_{4}: \mathrm{N}_{150} \mathrm{P}_{75} \mathrm{~K}_{37.5}$ & 8.19 & 0.34 & 4.9 & 238.16 & 16.18 & 163.25 \\
\hline $\mathrm{SEm} \pm$ & 0.02 & 0.01 & 0.00 & 2.84 & 0.66 & 2.89 \\
\hline CD (0.05) & NS & NS & NS & 8.20 & 1.89 & 8.35 \\
\hline Interaction & NS & NS & NS & NS & NS & NS \\
\hline Initial Status & 8.15 & 0.32 & 4.6 & 233.27 & 13.42 & 149.62 \\
\hline
\end{tabular}


fertility levels and varieties. Significantly higher plant height $(91.50 \mathrm{~cm})$ was obtained with higher fertility level of 150:75:37.5 N-P $\mathrm{O}_{5}-\mathrm{K}_{2} \mathrm{O} \mathrm{kg} \mathrm{ha}{ }^{-1}$ at harvesting stage. During the entire period of study, the lowest plant height was observed in case of control $(0: 0: 0 \mathrm{~N}$ $\left.\mathrm{P}_{2} \mathrm{O}_{5}-\mathrm{K}_{2} \mathrm{O} \mathrm{kg} \mathrm{ha}{ }^{-1}\right)$. Application of varying level of fertilizers in rice under aerobic conditions had significant influence on number of tillers $\mathrm{m}^{-2}$ at $30,60,90$ and $120 \mathrm{DAS}$ and at harvesting stage (Fig. 2). Increase in number of tillers $\mathrm{m}^{-2}$ was recorded only up to 90 DAS thereafter, it declined gradually up to maturity. Maximum number of tillers $\mathrm{m}^{-2}$ (284.17) recorded at harvesting stage with fertility level of 150: 75: $37.5 \mathrm{~N}$ $\mathrm{P}_{2} \mathrm{O}_{5}-\mathrm{K}_{2} \mathrm{O} \mathrm{kg} \mathrm{ha}{ }^{-1}$ and showed superiority with magnitude of $71.8,18.6$ and 4.7 per cent over other fertility levels viz. control, 90: 45: 22.5 and 120: 60: $30 \mathrm{~N}-\mathrm{P}_{2} \mathrm{O}_{5}$ $-\mathrm{K}_{2} \mathrm{O} \mathrm{kg} \mathrm{ha}{ }^{-1}$, respectively. The abundant supply of $\mathrm{N}$, $\mathrm{P}$ and $\mathrm{K}$ is considered essential for growth and development of rice. NPK fertilization leads to increase in plant height and number of tillers $\mathrm{m}^{-2}$. Similar findings i.e. increase in fertility levels leads to increase in plant height and number of tillers of rice have been reported by Sowmyalatha et al. (2012) and Songyikhangsuthor et al. (2014).

The performance of rice varieties also differed significantly under aerobic conditions. In general, plant height of different rice varieties increased till 120 DAS with the advancement of age of crop plant. Among the different varieties, PAC-837 variety recorded the highest and variety PR-121 recorded lowest plant height at all the growth stages. Maximum number of tillers $\mathrm{m}^{-2}$ was observed in variety PAC- 837 at all growth stages. Number of tillers $\mathrm{m}^{-2}$ (fig. 2) increased up to 90 DAS in all varieties. Lowest tiller count $\mathrm{m}^{-2}$ was recorded in PR-121. This might be due to differential genetic makeup of varieties and ability to accumulate the photosynthates in the vegetative plant parts. Significant differences in plant growth characteristics of rice as influenced by various genotypes under aerobic conditions were also reported by Parashivamurthy et al. (2012).

Yield and yield attributes: Fertility levels and varie-

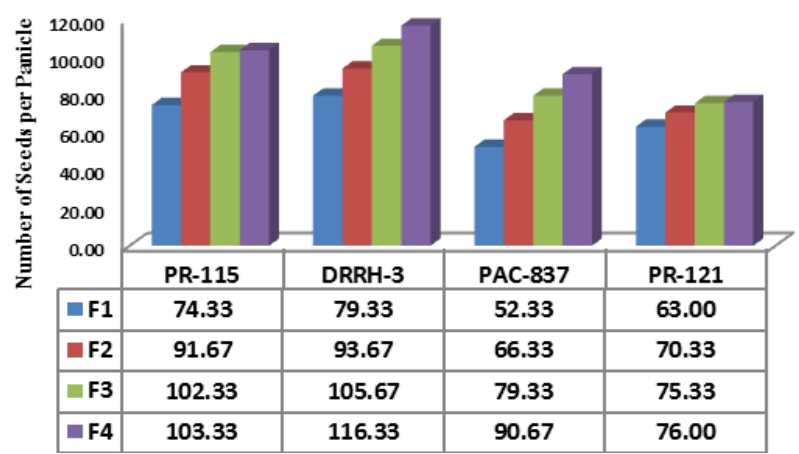

Fig. 5. Interaction effect of different rice varieties and fertility levels on number of seeds per panicle under aerobic conditions. ties significantly influenced all the yield attributes viz. number of effective tillers $\mathrm{m}^{-2}$, number of seeds per panicle, 1000-grain weight, spikelet sterility, grain yield, straw yield and harvest index. The number of effective tillers $\mathrm{m}^{-2}$ significantly increased up to 120 : 60: $30 \mathrm{~N}-\mathrm{P}_{2} \mathrm{O}_{5}-\mathrm{K}_{2} \mathrm{O} \mathrm{kg} \mathrm{ha}{ }^{-1}$ thereafter non significant difference was noticed. Highest number of effective tillers $\mathrm{m}^{-2}$ was recorded at fertility dose of 150: 75: $37.5 \mathrm{~N}-\mathrm{P}_{2} \mathrm{O}_{5}-\mathrm{K}_{2} \mathrm{O} \mathrm{kg} \mathrm{ha}{ }^{-1}$ with superiority of $71.9,15.4$ and 2.5 per cent over control, 90:45:22.5 and 120: 60: $30 \mathrm{~N}-\mathrm{P}_{2} \mathrm{O}_{5}-\mathrm{K}_{2} \mathrm{O} \mathrm{kg} \mathrm{ha}{ }^{-1}$. Increased level of fertilizer application up to 150: 75: $37.5 \mathrm{~N}_{-} \mathrm{P}_{2} \mathrm{O}_{5}-\mathrm{K}_{2} \mathrm{O} \mathrm{kg} \mathrm{ha}{ }^{-1}$ resulted in increased number of seeds per panicle. The spikelet sterility decreased with increase in fertility levels. Lowest spikelet sterility $(17.57 \%)$ was recorded in 150: 75: $37.5 \mathrm{~N}-\mathrm{P}_{2} \mathrm{O}_{5}-\mathrm{K}_{2} \mathrm{O} \mathrm{kg} \mathrm{ha}^{-1}$ which was however, statistically at par with 120: 60: $30 \mathrm{~N}-\mathrm{P}_{2} \mathrm{O}_{5}-\mathrm{K}_{2} \mathrm{O}$ $\mathrm{kg} \mathrm{ha}^{-1}(18.38 \%)$. Non significant difference in 1000 seed weight was observed in response to increasing fertility levels. The grain and straw yield increased up to $150: 75: 37.5 \mathrm{~N}-\mathrm{P}_{2} \mathrm{O}_{5}-\mathrm{K}_{2} \mathrm{O} \mathrm{kg} \mathrm{ha}{ }^{-1}$. Maximum grain yield $\left(52.78 \mathrm{q} \mathrm{ha}^{-1}\right)$ was observed in fertility level of 150:75:37.5 N-P $\mathrm{P}_{2} \mathrm{O}_{5}-\mathrm{K}_{2} \mathrm{O} \mathrm{kg} \mathrm{ha}{ }^{-1}$ with a magnitude of superiority of $5.31,34.6$ and 153.0 per cent over 120:60:30 N- $\mathrm{P}_{2} \mathrm{O}_{5}-\mathrm{K}_{2} \mathrm{O} \mathrm{kg} \mathrm{ha}{ }^{-1}, 90: 45: 22.7 \quad \mathrm{~N}^{-} \mathrm{P}_{2} \mathrm{O}_{5}$ $\mathrm{K}_{2} \mathrm{O} \mathrm{kg} \mathrm{ha}{ }^{-1}$ and control, respectively. Lowest grain yield was observed with control (0: 0: 0 N- $\mathrm{P}_{2} \mathrm{O}_{5}-\mathrm{K}_{2} \mathrm{O}$ $\left.\mathrm{kg} \mathrm{ha}^{-1}\right)$. The harvest index found to be non significant irrespective of fertility levels. Increased applications of fertilizers are responsible for greater root development followed by higher nutrient uptake and leaf area development consequently significant improvement in yield and yield attributes. Further, this might be because of increased $\mathrm{CO}_{2}$ assimilation resulting from increased nutrient uptake by application of higher doses of nutrient level. Similar findings were reported by Mahajan et al. (2012), Mallareddy et al. (2013) and Uddin et al. (2013). Vanitha and Mohandass (2014) also reported that spikelet number, grain and straw yield of rice increased due to increase in source size and activity a result of increased fertility levels.

The performance of rice varieties differed significantly under aerobic conditions. Rice variety PAC- 837 recorded significantly higher effective tillers $\mathrm{m}^{-2}$ (264.00), grain yield (45.65 q ha-1), straw yield (59.98 $\left.\mathrm{q} \mathrm{ha}^{-1}\right)$ and harvest index which were however, statistically at par with DRRH-3 except grain yield and effective tillers $m$ ${ }^{-2}$. This might be attributed to higher affinity of these varieties to produce more number of tillers $\mathrm{m}^{-2}$ in early growing period followed by differential ability of cultivars to utilize the fertilizer nutrients as well as partitioning of photoassimilates. Ndaeyo et al. (2008) and Mahajan et al. (2012) also reported differential ability of partitioning of dry matter and utilization of available nutrients by various varieties of rice. Higher number of seeds panicle ${ }^{-1}$ were recorded in rice variety DRRH-3 followed by PR-115 and lower number of seeds per 
panicle were reported by PR-121. This might be attributed to genetic makeup of different rice cultivars. Variation in number of seeds panicle ${ }^{-1}$ with rice varieties was reported by Ramanjaneyulu et al. (2014) and Mahajan et al. (2012). Higher 1000-grain weight was recorded in PR-121 as compared to other varieties which may be due to ability of this cultivar to partition dry matter towards seeds. These results corroborate the findings of Onaga et al. (2012). Similarly, Kastura and Nakaide (2011) found that the rice varieties with greater sink capacity and source activity per plant could produce heavier grain weight under aerobic conditions. Spikelet sterility also reported highest in rice variety PR-121 (29.89 \%). Reddy et al. (2012) also reported variation in spikelet sterility of rice among the different rice cultivars.

Interaction effect of varieties and fertility levels (fig 3, 4 and 5) revealed that hybrid varieties, DRRH-3 and PAC-837 responded significantly up to fertility levels of 150: 75: $37.5 \mathrm{~N}-\mathrm{P}_{2} \mathrm{O}_{5}-\mathrm{K}_{2} \mathrm{O} \mathrm{kg} \mathrm{ha}{ }^{-1}$ in term of number of seeds panicle ${ }^{-1}$, grain and straw yield whereas, rice varieties, PR-115 and PR-121 responded only up to 120: $60: 30 \mathrm{~N}-\mathrm{P}_{2} \mathrm{O}_{5}-\mathrm{K}_{2} \mathrm{O} \mathrm{kg} \mathrm{ha}{ }^{-1}$. Highest grain yield of $59.81 \mathrm{q} \mathrm{ha}^{-1}$ was recorded from the variety PAC-837 with 150: 75: $37.5 \mathrm{~N}-\mathrm{P}_{2} \mathrm{O}_{5}-\mathrm{K}_{2} \mathrm{O} \mathrm{kg} \mathrm{ha}{ }^{-1}$. Variety PR121 with no application of fertilizers recorded lowest grain yield $\left(18.36 \mathrm{q} \mathrm{ha}^{-1}\right)$. This may be due to the reason that hybrids have greater nutrient utilization capacity. The interactions between rice varieties (Vikas, Doddabyranellu, Thanu, Rasi and BPT-5204) and fertility levels under aerobic conditions also have been reported by Parsahivamurthy et al. (2012).

Soil chemical properties: After harvesting of rice crop, soil samples were analyzed treatment wise (Table 2) and it was observed that the effect of treatments on soil $\mathrm{pH}, \mathrm{EC}$ and $\mathrm{OC}$ was non significant however, increase in fertility levels resulted in increase in soil available $\mathrm{N}, \mathrm{P}_{2} \mathrm{O}_{5}$ and $\mathrm{K}_{2} \mathrm{O}$. Among the various fertility levels, available $\mathrm{N}, \mathrm{P}_{2} \mathrm{O}_{5}$ and $\mathrm{K}_{2} \mathrm{O}$ in soil improved significantly with increased application of fertilizers from control to 150: 75: $37.5 \mathrm{~N}-\mathrm{P}_{2} \mathrm{O}_{5}-\mathrm{K}_{2} \mathrm{O} \mathrm{kg} \mathrm{ha}{ }^{-1}$. Highest available $\mathrm{N}, \mathrm{P}$ and $\mathrm{K}$ in soil were observed in 150: 75: $37.5 \mathrm{~N}-\mathrm{P}_{2} \mathrm{O}_{5}-\mathrm{K}_{2} \mathrm{O} \mathrm{kg} \mathrm{ha}{ }^{-1}$. This might be due to increased application of fertilizers that leave some residual nutrient in soil besides nutrient uptake be crop. Similar results of rice were also observed by Choudhary and Suri (2014) and Yuanqiu He et al. (2007). Further, it was also observed that increased root growth of rice with increased application of fertilizers added nutrients in soil after decaying (Devi et al., 2012).

Rice varieties could not bring any significant effect on the $\mathrm{pH}, \mathrm{EC}$ and organic carbon of the soil but available $\mathrm{N}, \mathrm{P}$ and $\mathrm{K}$ differed significantly among the varieties at $5 \%$ level of significance. However, a marginal increase in soil $\mathrm{pH}, \mathrm{EC}$ and organic carbon content of soil was noticed. Significantly higher available nitro- gen, phosphorus and potassium in soil was recorded with PR-121 and lowest available major nutrients was recorded with variety $\mathrm{PAC}-837$. This might be due to differential uptake of $\mathrm{N}, \mathrm{P}$ and $\mathrm{K}$ by rice cultivars. Rice variety PR-121 recorded lowest uptake of nutrient which might brings more nutrient status in soil. Fageria et al. (2010) also reported differential soil nutrient status after harvest of rice crop and observed that highest available $\mathrm{N}, \mathrm{P}_{2} \mathrm{O}_{5}$ and $\mathrm{K}_{2} \mathrm{O}$ in soil with variety that uptake significantly lower $\mathrm{N}, \mathrm{P}$ and $\mathrm{K}$ by both grain and straw.

\section{Conclusion}

From the present study, it can be inferred that nutrientmanagement system through judicious use of chemical fertilizers along with suitable varieties can play a key role for improving crop productivity and soil fertility under aerobic conditions. The study conclusively revealed that application of 150: 75: $37.5 \mathrm{~N}-\mathrm{P}_{2} \mathrm{O}_{5}-\mathrm{K}_{2} \mathrm{O}$ $\mathrm{kg} \mathrm{ha}^{-1}$ coupled with suitable germplasm viz. PAC-837 and DRRH-3 can prove to be a boon to enhance plant growth \& development and productivity of rice under aerobic conditions in northwestern Himalayas. Higher yield attributes were recorded highest in PAC-837 which was however, statistically at par with DRRH-3 except grain yield and effective tillers $\mathrm{m}^{-2}$. Rice variety PAC-837 recorded highest grain yield of $45.65 \mathrm{q} \mathrm{ha}^{-1}$ and straw yield of $59.98 \mathrm{q} \mathrm{ha}^{-1}$. The grain and straw yield increased up to $150: 75: 37.5 \mathrm{~N}-\mathrm{P}_{2} \mathrm{O}_{5}-\mathrm{K}_{2} \mathrm{O} \mathrm{kg}$ ha ${ }_{1}$ and recoded grain yield of $52.78 \mathrm{q} \mathrm{ha}^{-1}$ and straw yield of $73.85 \mathrm{q} \mathrm{ha}^{-1}$ with application of 150: 75: 37.5 $\mathrm{N}-\mathrm{P}_{2} \mathrm{O}_{5}-\mathrm{K}_{2} \mathrm{O} \mathrm{kg} \mathrm{ha}{ }^{-1}$. Nutrient application of 150: 75: $37.5 \mathrm{~N}-\mathrm{P}_{2} \mathrm{O}_{5}-\mathrm{K}_{2} \mathrm{O} \mathrm{kg} \mathrm{ha}{ }^{-1}$ recorded highest available $\mathrm{N}$, $\mathrm{P}$ and $\mathrm{K}$ in soil after harvest of the crop. Higher available nitrogen, phosphorus and potassium $\mathrm{n}$ soil were recorded with PR-121.

\section{REFERENCES}

Anonymous. (2015). Agricultural Statistics at a Glance. Directorate of Economics \& Statistics. Ministry of Agriculture Department of Agriculture \& Cooperation. Government of India.

Bouman, B. A. M., Wang, H., Yang, X., Zhao, J and Wang, C. (2002). Aerobic Rice (Han Dao): A New Way of Growing Rice In Water-Short Areas. In: Proceedings of the 12th International Soil Conservation Organization Conference, 26-31 May, 2002, Beijing, China. Tsinghua University Press, Pp. 175-181

Carriger, S. and Vallee, D. (2007). More crop per drop. Rice Today, 6 (2): 10-13

Choudhary, A. K. and Suri, V. K. (2014). Integrated nutrient management technology for direct seeded upland rice (Oryza sativa L.) in Northwestern Himalayas. Communications in Soil Science and Plant Analysis, 45:777784

Devi, G. M., Reddy, S. T., Sumati, V., Partima, T. and John, K. (2012). Nitrogen management to improve the nutrient uptake, yield and quality parameters of scented rice under aerobic culture. International Journal of Applied 
biology and Pharmaceuticel Technology, 3(1): 340-344

Fageria, N. K., Morais, O. P. D. and Santos, A. B. D. (2010). Nitrogen use efficiency in upland rice genotypes. Journal of Plant Nutrition, 33: 1696-1711

Gomez, K. A. and Gomez, A. A. (1984). Statistical procedures for agricultural research. New York: John Wiley and Sons.

Jackson, M. L. (1967). Soil chemical analysis. New Delhi: Prentice Hall of India.

Jackson, M. L. (1973). Soil Chemical Analysis. Pp. 165-167. Asia publication house, Bombay.

Kastura, K. and Nakaide, Y. (2011). Factors that determine grain weight in rice under high yielding aerobic culture: The importance of husk size. Field Crops Research, 123: $266-272$

Mahajan, G., Timsina, J., Jhanji, S., Sekhon, N. K. and Singh, K. (2012) Cultivar response, dry matter portioning and nitrogen use efficiency in direct seeded rice in northwest India. Journal of Crop Improvement, 26: 767 $-790$

Mallareddy, M and Padmaja, B. (2013). Response of rice varieties to nitrogen under aerobic and flooded conditions. Indian Journal of Agronomy, 58(4): 500-505

Ndaeyo, N. U., Iboko, K. U., Harry, G. I. and Edem, S. O. (2008). Growth and yield performance of some upland rice cultivars as influenced by varied rates of NPK fertilizer on an ultisol. Journal of Tropical Agriculture, Food, Environment and Extension, 7(3): 249-255

Olsen, S. R., Cole, C. V., Watanable, F. S. and Dean, L. A. (1954). Estimation of available phosphorus in soils by extracting with sodium bicarbonate. United State Department of Agriculture Circulation, Pp. 939

Onaga, G. (2012). Comparison of response to nitrogen between upland NERICAs and ITA (Oryza sativa) rice varieties. Journal of Agricultural Science, 4(6): 197205

Parashivamurthy, S., Prashad, R., Lakshmi, J. and Ramachandra, C. (2012). Influence of varieties and fertilizer levels on growth, seed yield and quality of rice under aerobic conditions. Mysore Journal of Agricultural Sciences, 46(3): 602-609

Ramanjaneyulu, A. V., Gourishankar, V., Neelima, T. L and Shashibhushan, D. (2014). Genetic analysis of rice genotypes under aerobic conditions on alfisols. $S A$ BRAO Journal of Breeding and Genetics, 46(1): 99-111

Reddy, M. M., Padmaja, B., Veeranna, G. and Reddy, D. V. V. (2012). Evaluation of popular kharif rice varieties under aerobic conditions and their response to nitrogen dose. Journal of Research ANGRAU, 40(4): 14-19

Songyikhangsuthor, K., Sybounheuang, S. and Samson, B. K. (2014). Response of rice landraces and promising cultivars to nitrogen fertilizer on sloping uplands. International Journal of Agricultural Science Research, 3(9): 181-186

Sowmyalatha, B. S., Ramachandra, C., Shivakumar, N. and Manjunatha, K. B. (2012). Effect of methods of cultivation and fertility levels on growth and yield of rice hybrids. Mysore Journal of Agricultural Sciences, 46(1): 171-173

Subbiah, B. V. and Asija, G. L. (1956). A rapid procedure for the estimation of available nitrogen in soil. Current Science, 25: 259-260

Tuong, T. P. and Bouman B. A. M. (2001). Field water management to save water and increase its productivity in irrigated rice. Agricultural Water Management, 49: 1130

Uddin, S., Sarkar, M. A. R. and Rahman, M. M. (2013). Effect of nitrogen and potassium on yield of dry direct seeded rice cv. NERICA 1 in aus season. International Journal of Agronomy and Plant Production, 40(1): 6975

Vanitha, K. and Mohandass, S. (2014). Drip fertigation could improve source- sink relationship of aerobic rice (Oryza sativa L.). African Journal of Agricultural Research, 9 (2): 294-301

Walkley, A. J. and Black, C. A. (1934). An examination of the Dagtjareff method of determining soil organic matter and a proposed modification of the chromic acid titration method. Soil Science, 37: 29-38

Yoshida, S. (1981). Fundamental of Rice Crop Science. Int. Rice Res. Institute, Manila, Philippines, P. 129

Yuanqiu He, Shen, Q., Kong, H., Xiong, Y. and Wang, X. (2007). Effect of soil moisture content and phosphorus application on phosphorus nutrition of rice cultivated in different water regime systems. Journal of Plant Nutrition, 27(12): 2259-2272 